\title{
Credit Management Practices, Loan Repayment Management And Profitability Of Commercial Banks' Branches In Uganda.
}

\author{
Anthony Elemu ${ }^{a, 1}$ \\ a Faculty Of Graduate Studies And Research, Makerere University, \\ P.O. Box 7072, Kampala, Uganda.
}

\begin{abstract}
\end{abstract}

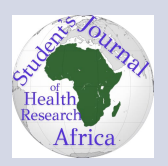

Background:

The study examined the relationship between credit management practices, loan repayment management and profitability of commercial banks branches in Uganda. The objectives included; to establish the relationship between credit management practices and profitability; relationship between loan repayment management and profitability; mediating effect of loan repayment management on credit management practices and profitability; and examine the impact of credit management practices and loan repayment management on profitability.

\section{Methodology:}

The study was a cross- sectional research and applied a quantitative approach. A sample of 234 commercial bank branches was used from a total of 573 . The study obtained responses from 166 branches. Primary data was obtained from a branch manager and credit supervisor using a structured questionnaire. Validity of the questionnaire was obtained using CVI and reliability using Cronbach Alpha Coefficient. Data was analyzed using SPSS v.20 to obtain descriptive statistics, correlation and regression analyzes to present results. A Med-graph was used to test the mediation of loan repayment management.

Results:

This study ascertained a positive relationship between credit management practices and profitability; and positive relationship between loan repayment management and profitability. The study further ascertained a partial mediation of loan repayment management in the relationship between credit management practices and profitability. Furthermore, the study revealed that jointly credit management practices and loan repayment management predict profitability of commercial bank branches. More so, the study established that the best predictor of profitability is loan repayment management. This study ascertained a positive relationship between credit management practices and profitability; and positive relationship between loan repayment management and profitability.

\section{Conclusion:}

The study concludes that credit management practices and loan repayment management are among the critical factors influencing profitability at commercial bank branch level.

\section{Recommendations: ${ }^{a}$}

The study recommends commercial bank branches to carryout continuous loan monitoring and control; loan appraisal; and proper documentation.

\footnotetext{
${ }^{a}$ Date submitted: 02-10-2021

Date accepted: 27-10-2021 Email: aelemu@gmail.com
} 


\section{Background:}

One of the core objectives of every financial institution is to run a profitable business (Tebajjukira \& Joji, 2015). With a profitable business, the financial institution is likely to survive, grow and ensure sustainable operations. Similarly, in line with the going concern concept, several scholars argue that an institution has to be profitable to remain operational in the ever competitive and challenging environment explaining why practitioners have pushed for strategies to promote profit generation within different institutions (Lagat, Mugo \& Otuya, 2013). Despite the relevance of profitability, it has been highlighted in a number of studies that commercial banks branches are still finding it hard to maintain a consistent level of profitability.

Profitability remains one of the major concerns among commercial banks branches from the global, regional and local perspective (Abbasi \& Weigand, 2017; Raghunandan et al., 2012). Banks of Alliance, Hume and Franklin consistently reported $\$ 391$ million decline in profits which resulted in their closure. A survey by Winterboer (2016) indicates that over $65 \%$ of commercial banks branches experience decline in profit. In East Africa, banks have registered low profits due to rising bad debt. According to a report in the East African by James Anyanzwa in 2018 , on average, banks' profitability as measured by their return on assets decreased from 2.8 per cent in the year to June 2016 to 2.3 per cent in the year to June 2017 (The East African, Monday March 19 2018). Bank of Uganda (BOU, 2015) indicates that the Return on Equity (ROE) for commercial banks branches declined from 16.1 percent to 16.0 percent between 2014 and 2015. Between 2015 and 2016, profitability of commercial banks

branches declined by 44.2 percent from USh.541.2 billion to USh.302.1 billion respectively. Moreover, the Return On Equity (ROE) also declined from 17.7 percent to 13.8 percent and Return on Assets (ROA) declined from $2.8 \%$ in 2015 to 2.2 percent in 2016 (BOU, 2016a). In 2017 the sector again registered a decline in profitability as a result of more provisioning and increased operating costs, (BOU, 2016b). Precisely the banking sector recorded a decrease in Return on Asset and Return on Equity in June 2016 to June 2017 from 2.2 percent and 13.8 percent to 1.7 percent and 10.2 percent respectively.
Asymmetric information theory explains that credit provision exercise encounters information asymmetry which results in inefficient decisions by managers. To bridge this gap, managers are supposed to come up with best practices regarding how to evaluate credit, administer and gather information from customers before extending credit (Zu \& Kaynak, 2012). In essence, the theory emphasizes that effectiveness of credit management practices enables managers to come up with best decisions regarding credit extension. Credit management practices refer to systems, guidelines and principles that are put in place to serve as a blueprint whenever employees are extending credit to customers (Asantey \& Tengey, 2014). There is consensus that credit management practices increase management efficiency in utilizing organizational resources to generate profits (Kessey, 2015).

The theory states that when credit decisions are based on sufficient subjective and quantitative information, the institution is able to avoid adverse selection of borrowers to adversely avoid moral hazards in terms of non-performing loans and become profitable (Glover \& Levine, 2016). Some of the empirical studies (Gul, Irshad \& Zaman, 2011; Muritala \& Taiwo, 2013; Mwinlaaru, Ofori, Adiyiah \& Idun, 2016) concur that credit management practices and loan repayment

management are necessary in determining profitability. More so, Gul et al., (2011) reveal that with prudent credit management practices, managers are able to make realistic decisions which would safeguard the institution losses arising from accounts receivable hence making the financial institution more profitable. On the other hand, Balango and Rao (2017) indicate that loan portfolio management is indispensable in profitability.

The current lacuna as far as credit management practices and loan repayment management is concerned is that most of the available studies related to these variables have been conducted among Asian and European countries (Fendi, Sawalha, Shamieh \& Jaara, 2017; Menicucci \& Paolucci, 2016; Vinh, 2017) or among countries located in West Africa (Adekunle, Alalade, Agbatogun \& Abimbola, 2015; Asantey \& Tengey, 2014). Even then, such studies have studied commercial banks branches from a broader perspective tackling it as a whole, without necessarily seeking an understanding of the influence of the same concepts in relation to branches which are the core determinants of the 
profitability status of the whole commercial bank. As such, this study seeks to close this knowledge gap and by focusing more on customer interactions and follow up.

The banking industry in Uganda has grown as evidenced by the increase in commercial banks branches since the lifting of the moratorium however; there is still an issue of profitability which has consistently declined. Table 1.1 indicates a decline from USh.556.3 billion in 2015 to USh.404.5 billion in 2017 reflecting a drop of 27.2 percent (BOU Report, 2016a; 2016a). The results of the stress tests also revealed that a default by the banks' top three customers and an increase in nonperforming loans would lead to big potential losses by commercial banks branches (BOU, 2016b)

\section{Methodology: \\ Research Design}

The study adopted a cross-sectional research design along with a quantitative research approach. The design was selected to enhance large sample coverage considering that data is obtained just once from each of the selected samples (Field, 2009). The quantitative research approach was applied to provide clarity of analysis regarding the cause and effect relationship between variables.

\section{Study Population}

The study population comprised of commercial bank branches in Uganda. BOU (2016) revealed a total of 573 branches. This study focused on branches because the consolidated profitability is reliant upon the performance of the respective branches. In other words, branches are the main sources of business in a commercial bank's setting. These branches constituted the unit of analysis.

\section{Sample size and Selection technique}

The study used a sample of 234 branches which was determined based on Krejcie and Morgan's (1970) table for selecting samples from a given population. This study applied stratified random

sampling technique to obtain the branches which constituted the sample. This technique involves the stratification of the sample before simple random sampling is applied. In this study, the branches for every commercial bank were separated to form 24 different strata from which the sample would be selected. This was applied to guarantee that every commercial bank is represented and representative enough irrespective of the heterogeneity in- volved (Field, 2009). The researcher then applied a simple random sampling technique which involves selecting the required number of branches from each stratum one element at a given time without replacing until the numbers were obtained. This technique was applied to ensure unbiased sample selection since it accords every element within the population equal opportunity of being selected.

From the selected branches, the researcher was interested in two people, that is; the branch manager and credit supervisor who served as the unit of inquiry. These were selected using the purposive sampling technique because they were deemed primarily responsible for the profitability of the branch. Notable, the branch manager is the overall of all activities that take place at the branch while the credit supervisor plays a commendable role in ensuring that credit as the primary business is conducted as expected. These two respondents were therefore deemed fit to explain issues of credit management practices, loan repayment management, and profitability at the branch level.

\section{Data sources}

Primary data was used in the analysis and interpretation of results. This was obtained directly from the managers and credit supervisors across the sampled branches. Primary data was selected to base the analysis on recent information related to credit management practices, loan repayment management, and profitability.

\section{Data Collection Instrument}

The study uses a structured questionnaire to collect data. The questionnaire contained only closedended questions gauged on a 5-Likert scale based on a scale from 5 (Strongly agree) to 1 (Strongly disagree) and was self-administered by the researcher. The instrument was used to allow collecting views from a highly diverse and large sample (Field, 2009).

\section{Validity and Reliability}

The validity of the data collection instrument was determined by Content Validity Index (CVI) to assess whether the items contained in the instrument were good measures and easily understandable. This was confirmed under guidance by Field (2009) who revealed that an instrument is valid if the CVI for each construct and overall primary variables is $0.7+$. The obtained results are presented in Table 1.

Reliability was determined through pretesting and testing of Cronbach Alpha Coefficients from SPSS. The researcher distributed between 15-20 
questionnaires prior to the actual data collection. Based on the comments and views obtained, the final instrument was amended. After the data collection exercise, the study obtained Cronbach Alpha Coefficient proposed by Cronbach (1951). This parametric test is a reliable test for determining the internal consistency of the collected data. Nunnally (1978) highlighted that field results can only qualify as reliable if the Cronbach Alpha Coefficient is at least 0.7 . This applies to the primary variables and their respective constricts. The results in this regard are summarized in Table 1.

\section{Table 1: Validity and Reliability Results}

Table 1 above indicates that the CVI for the studied variables was above the 0.7 thresholds. Thus, the items used in the instrument were good measures of the constructs under which they were presented. Results further indicate that the Cronbach Alpha Coefficient for each variable surpasses the cutoff of 0.7. It is conclusive that the results acquired from the field were reliable and fit for making conclusions and recommendations.

\section{Measurement of variables}

Variables were conceptualized and measured using constructs obtained from numerous scholars and academia (Balango \& Rao, 2017; Delen et al., 2013; Hassanpoor \& Pourali, 2013; Heikal et al., 2014; Kavata, 2016; Kharatyan et al., 2017; Uwuigbe et al., 2015).

Credit Management Practices was conceptualized in terms of documentation, appraisal, and approval (Asante, et al., 2016; Kessey, 2015; Klotz \& Lindermeir, 2015; Uwuigbe et al., 2015). This study further adopted a 20-Item measure of credit management practices from Asante, et al., (2016) and Kessey (2015) which were modified to fit the context of the study. Examples of the adopted items include "We have a document checklist that must be followed to complete a loan file" for documentation, "We carry out know your customer (KYC) for both old and new customers in our institution" for appraisal, and "The amount is first verified before it is fully approved" for approval.

Loan repayment management was conceptualized in terms of performing loans, non-performing loans, and credit policy/administration (Cucinelli, 2015; Fendi et al., 2017; Ozili et al., 2017). A
The 15-Items measure was adopted from Fendi et al., (2017) and modified accordingly to suit the context of this particular study. Some of the items such as "Our Portfolio at Risk (PAR) has increased compared to the previous period" for non-performing loans, "Our clients repay their loan installments on time" for performing loans, and "Our bank has a written down lending rules and guidelines" for credit policy/administration were applied.

The profitability variable was conceptualized using constructs of Return on Assets, operation expenses, and operating income (Delen et al., 2013; Hassanpoor \& Pourali, 2013; Heikal et al., 2014; Kharatyan et al., 2017). The study further adopted a 20-Items measure from (Hernaus, Bach \& Vukšić, 2012; Kazan, Özer \& Çetin, 2006) which were modified to fit the context of the study. Samples of the adopted items include, "Our net income over total assets of our branch is higher than the bank average" for ROA, "Our branch's number of employees has increased lately compared to the previous year" for operating expenses, and "Our branch fees and commissions receivable have increased in this year compared to the previous" to assess operating income.

\section{Ethical considerations}

This study complied with specific ethical issues. All the data collected in this study was used strictly for academic purposes. The researcher made sure that the questions contained in the instrument were strictly to guide addressing the objectives. Confidentiality of respondents was considered primarily as the researcher never solicited for either a contact or name of respondents. Participation in the study was also voluntary and every potential respondent had the right to either accept or decline to fill the instrument. The researcher sought authorization from the management of the different commercial banks' branches before the human resource of the selected branches was engaged.

\section{Data Analysis, Presentation, and Interpreta-} tion

Data was sorted, edited, and cleaned before it is entered in Statistical Package for Social Scientists (SPSS. Version 20) for analysis. The study used descriptive statistics and inferential statistics to present and interpret results. Descriptive statistics, specifically the frequency tables were used for demographic characteristics. The inferential statistics used in the study include correlation analysis, 
Table 1. Validity and ReliabilityResults

\begin{tabular}{llll}
\hline Variable/Construct & Cronbach's Alpha & Content Validity Index & N of Items \\
Credit Management Practices & .828 & .800 & 20 \\
\hline
\end{tabular}

\begin{tabular}{llll}
\hline Loan Repayment Management & .807 & .867 & 15 \\
Profitability & .837 & .800 & 20 \\
\hline primary data & & &
\end{tabular}

regression analysis, and Sobel z-value. Correlation Analysis examined the relationship between study variables. The analysis guided the study in providing answers to research questions one to three. Sobel z-value along with a hierarchical regression model was used to address research question four. Multiple regression analysis was used to test examine the impact of the studied variables and subsequently address research question five.

\section{PRESENTATION AND INTERPRETATION OF RE-}

\section{SULTS}

\section{Response Rate}

Out of 234 branches that were supposed to participate in this study, this study managed to obtain responses from 166 giving a response rate of 70.9 percent. In other words, this study was able to obtain data from at least 70 percent of the sample size upon which such data is considered representative enough to be generalized (Amin, 2005).

\section{Descriptive Statistics}

This study used frequency tables to indicate results in relation to the demographic characteristics of respondents. These characteristics were twofold, one in terms of institutional characteristics while others were in relation to the respondents who actively participated in the instrument.

\section{Branch Characteristics}

This study obtained results regards to the years of operation, branch network, total asset value, customer size, and an average number of employees. These results are presented in Table 1.

\section{Table 2: Commercial Banks' Branch Characteristics}

Source: Primary Data

Indicated that most branches have been in existence for a period between 16 and 20yrs (28.3 percent). This statistic signifies stability and growth which could enhance profitability. The assets value for branches has also been established to range between 1 and 6 billion (48.2 percent). It could be suggested that most commercial branches in Uganda have a high profitability potential considering that the more assets, the more likely a firm can use such assets to generate income. Results indicate that most branches employees range between 10 and 15

(62.7 percent). This implies that most branches are large and require a sizable human resource to run the operations.

\section{Individual Characteristics}

This study obtained results in relation to gender, age bracket, education level, working experience, and position. These results are presented in Table .2.

\section{Table 2: Respondents' Characteristics}

table reveals that most of the respondents were male. The implication of this statistic is that most commercial banks branches entrust branch managerial positions to male staff compared to females. Perhaps, males could be generally regarded as more aggressive and more likely to direct commercial banks branches towards profitability as opposed to females. Furthermore, most respondents were aged between 30-39 yrs. In this regard, the statistics signify that the commercial banks' branches allocate branch managerial positions to employees who are relatively young who can exhibit a high level of aggressiveness, creativity, and innovation to improve profitability. In regards to education, results established that most respondents either had Bachelor's degree (31.9 percent) or a Master's (54.8 percent). The statistic portrays that most of the employees who are directed to 
Table 2. Commercial Banks'Branch Characteristics

\begin{tabular}{lll}
\hline $\begin{array}{l}\text { Characteristic } \\
\text { Years in existence }\end{array}$ & Frequency & Percent \\
Less than 5 yrs & 9 & 5.4 \\
5-10 yrs & 28 & 16.9 \\
$11-15$ yrs & 37 & 22.3 \\
16-20 yrs & 47 & 28.3 \\
21 and above & 45 & 27.1 \\
Total & 166 & $\mathbf{1 0 0 . 0}$ \\
Assets Value & & \\
Less than 1 bn & 54 & 32.5 \\
1-6 bn & 80 & 48.2 \\
6-9 bn & 22 & 13.3 \\
10 bn and above & 10 & 6.0 \\
Total & 166 & 100.0 \\
Employees & & \\
Less than 10 & 40 & 24.1 \\
10-15 employees & 104 & 62.7 \\
16 and above & 22 & 13.3 \\
Total & $\mathbf{1 6 6}$ & $\mathbf{1 0 0 . 0}$ \\
\hline
\end{tabular}

\begin{tabular}{|c|c|c|}
\hline $\begin{array}{l}\text { Characteristic } \\
\text { Gender }\end{array}$ & Gender & Percent \\
\hline Male & 212 & 63.9 \\
\hline Female & 120 & 36.1 \\
\hline Total & 332 & 100.0 \\
\hline \multicolumn{3}{|l|}{ Age } \\
\hline Less than 30 yrs & 65 & 19.6 \\
\hline 30-39 yrs & 155 & 46.7 \\
\hline $40-49$ yrs & 89 & 26.8 \\
\hline 50 yrs and above & 23 & 6.9 \\
\hline Total & 332 & 100.0 \\
\hline \multicolumn{3}{|l|}{ Education } \\
\hline Diploma & 29 & 8.7 \\
\hline Bachelor & 106 & 31.9 \\
\hline Master & 182 & 54.8 \\
\hline Others & 15 & 4.5 \\
\hline Total & 332 & 100.0 \\
\hline \multicolumn{3}{|l|}{ Experience } \\
\hline Less than 5 yrs & 22 & 6.6 \\
\hline 5-10 yrs & 82 & 24.7 \\
\hline 11 yrs and above & 228 & 68.7 \\
\hline Total & 332 & 100.0 \\
\hline
\end{tabular}

Source: Primary Data 
serve as branch managers or credit supervisors are highly educated, with enough acquired competencies to guide commercial bank's branches towards improving profitability. Lastly, the results obtained that most respondents had at least 11 years of experience. Such experience is critical in effective decision-making to ensure that branches become profitable.

\section{Correlation Analysis}

In order to establish the association between study variables, this study obtained Pearson Correlation Analysis. The results are presented in Table 3.

\section{Table 3: Pearson Correlation Analysis between study} variables

Credit Management Practices and Profitability reveals a significant positive relationship between credit management practices and profitability $(r=.534, p<.01)$. Thus, the statistics signify that an improvement in credit management practices is more likely to improve profitability among commercial banks branches. It is worth noting that credit management practices were correlated with profitability. The results indicate a significant positive relationship between documentation and profitability $(r=.412, p<.01)$. A significant positive relationship was also established between appraisal and profitability $(r=.397, p<.01)$. Correlation results further indicate a significant positive relationship between approval and profitability $(r=.412, p<.01)$. These results portray that improving credit management practices of documentation, appraisal, and approval is likely to enhance profitability among commercial banks branches.

Loan Repayment Management and Profitability indicates that there exists a significant positive relationship between loan repayment management and profitability $(r=.623, p<.01)$. The statistics imply that improving loan repayment management would enhance the profitability of commercial banks branches. Table 4 also revealed that the construct of Non-performing loans is significantly positively related to profitability $(r=.441, p<.01)$. The results further indicate that there exists a significant positive relationship between performing loans and profitability $(r=.441, p<.01)$ as well as a significant positive relationship between credit pol- icy/administration and profitability $(r=.481, p<.01)$. On that note, the statistics suggest that minimizing non-performing loans and improving performing loans along with credit policies are likely to enhance profitability among commercial banks branches. Results Indicates that there exists a significant positive relationship between loan repayment management and profitability $(r=.623, p<.01)$. The statistics imply that improving loan repayment management would enhance the profitability of commercial banks branches. Table 4 also revealed that the construct of Non-performing loans is significantly positively related to profitability $(r=.441, p<.01)$. The results further indicate that there exists a significant positive relationship between performing loans and profitability $(r=.441, p<.01)$ as well as a significant positive relationship between credit policy/administration and profitability $(r=.481, p<.01)$. On that note, the statistics suggest that minimizing non-performing loans and improving performing loans along with credit policies are likely to enhance profitability among commercial banks branches.

Testing the Mediation Effect of Loan Repayment Management in the relationship between Credit Management Practices and Profitability

Hierarchical regression analysis and Sobel zvalue were used to establish whether loan repayment management mediates the relationship between credit management practices and profitability. A hierarchical regression model was used to check whether the earlier conditions stipulated by Baron and Kenny (1986) were fulfilled. The Med Graph was used to derive the Sobel z-value and subsequently establish whether the conditions by Sobel (1982) are fulfilled. These results are presented using Table 4 and Figure 1.

\section{Table 5: Multiple regression analysis between study variables}

Table 5 obtained Adj R2=.449 which implied that jointly credit management practices and loan repayment management significantly predict $44.9 \%$ of the changes in profitability among commercial banks branches. Furthermore, the results indicate standardized coefficients $(\beta=.294, \mathrm{t}=6.198, \mathrm{p}<.05$ ) in relation to credit management practices and $(\beta=$ $.474, \mathrm{t}=10.010, \mathrm{p}<.05)$ in relation to loan repayment management. Based on the $p$-values, the results 


\begin{tabular}{|c|c|c|c|c|c|c|c|c|c|c|}
\hline Variable/Construct & & 1 & 2 & 3 & 4 & 5 & 6 & 7 & 8 & 9 \\
\hline Credit Management Practices & 1 & 1 & & & & & & & & \\
\hline Documentation & 2 & $.748^{* *}$ & 1 & & & & & & & \\
\hline Appraisal & 3 & $.783^{* *}$ & $.400^{* *}$ & 1 & & & & & & \\
\hline Approval & 4 & $.761^{* *}$ & $.374^{* *}$ & $.413^{* *}$ & 1 & & & & & \\
\hline Loan Repayment & 5 & .508 & $.390^{* *}$ & $.392^{* *}$ & $.380^{* *}$ & 1 & & & & \\
\hline Management & & $* *$ & & & & & & & & \\
\hline Non-Performing Loans & 6 & $.465^{* *}$ & $.296^{* *}$ & $.373^{* *}$ & $.401^{* *}$ & $.762^{* *}$ & 1 & & & \\
\hline Performing Loans & 7 & $.334^{* *}$ & $.314^{* *}$ & $.262^{* *}$ & $.197^{* *}$ & $.756^{* *}$ & $.444^{* *}$ & 1 & & \\
\hline Credit Policy/Admin & 8 & $.295^{* *}$ & $.237^{* *}$ & $.205^{* *}$ & $.219^{* *}$ & $.687^{* *}$ & $.303^{* *}$ & $.314^{* *}$ & 1 & \\
\hline Profitability & 9 & $\begin{array}{l}.534 \\
* *\end{array}$ & $.412^{* *}$ & $.397^{* *}$ & $.412^{* *}$ & .623 & $.441^{* *}$ & $.441^{* *}$ & $.481^{* *}$ & 1 \\
\hline **. Correlation is significant at th & 0. & 1 level & -tailed) & & & & & & & \\
\hline
\end{tabular}

\begin{tabular}{llll}
\hline Variable & Model 1 & Model 2 & Model 3 \\
Constant & 3.854 & 2.075 & 1.246 \\
Credit Management Practices & & $.536^{* *}$ & $.302^{* *}$ \\
Loan Repayment Management & & & $.463^{* *}$ \\
Control Variables & & & \\
Years & .059 & .023 & .003 \\
Branches & -.102 & $-.114^{* *}$ & -.046 \\
Assets & .013 & .034 & .021 \\
Customers & $-.139^{* *}$ & $-.154^{* *}$ & $-.052^{* *}$ \\
Employees & .092 & .060 & .014 \\
Model F & $2.316^{* *}$ & $25.388^{* *}$ & $42.196^{* *}$ \\
$\mathbf{R}$ & $.185^{a}$ & $.565^{b}$ & $.691^{c}$ \\
R2 & .034 & .319 & .477 \\
Adj R & .019 & .307 & .466 \\
$\Delta \mathbf{R}^{2}$ & .034 & .285 & .158 \\
Note: n=166 branches, Dependent Vari- & & \\
able=Profitability & & & \\
\hline
\end{tabular}

Table 4: Mediation Effect of LoanRepayment Management

Source: Primary Data

signify that both credit management practices and loan repayment management significantly predict profitability among commercial banks branches. That said, the comparative analysis of the Betavalues ( $\beta=.294$ and $\beta=.474$ ) reveals that loan repayment management is the best predictor of profitability.

\section{DISCUSSION, CONCLUSION, AND RECOMMENDATIONS \\ 9 Discussion of Findings}

The study compared and contrasted the ascertained findings to determine how the current findings are consistent or deviate from earlier stud- ies. The unique findings of the study were also expressed in this section.

Credit Management Practices and Profitability

The findings obtained a positive relationship between credit management practices and profitability among commercial banks branches. In light of the findings, it is postulated that enhancing credit management practices is likely to boost return on assets, operating income and set a platform upon which companies can minimize operating expenses among commercial banks branches. With the same view, this study argues that since credit management practices are directed towards loans, which are ideally the largest source of revenue for any financial institution, ensuring effective documen- 


\begin{tabular}{ll}
\hline $\begin{array}{l}\text { Type of mediation } \\
\text { Sobel z-value }\end{array}$ & Significant \\
95\% Symmetrical Confidence interval & $7.54042 \quad \mathrm{p}=<0.000001$ \\
Lower & $\mathbf{0 . 1 6 5 1 5}$ \\
Higher & $\mathbf{0 . 2 8 1 1 6}$ \\
Unstandardized indirect effect & \\
a*b & $\mathbf{0 . 2 2 3 1 6}$ \\
se & $\mathbf{0 . 0 2 9 5 9}$ \\
Effective Size measures & \\
Standardized Coefficients & \\
Total: & 0.534 \\
& \\
Direct: & $\mathbf{0 . 3 0 2}$ \\
Indirect: & $\mathbf{0 . 2 3 5}$ \\
Indirect to Total ratio & $\mathbf{0 . 4 4}$ \\
\hline Figure 1: Type of mediation & \\
Source:Primary Data & \\
\end{tabular}

\begin{tabular}{|c|c|c|c|c|c|c|c|}
\hline \multicolumn{3}{|c|}{ Unstandardized Coefficients } & \multicolumn{3}{|l|}{$\begin{array}{l}\text { Standardized } \\
\text { Coefficients }\end{array}$} & \multicolumn{2}{|c|}{$\begin{array}{l}\text { Collinearity } \\
\text { Statistics }\end{array}$} \\
\hline & B & $\begin{array}{l}\text { Std. } \\
\text { Error }\end{array}$ & Beta & $\mathbf{t}$ & Sig. & $\begin{array}{l}\text { Toler- } \\
\text { ance }\end{array}$ & VIF \\
\hline (Constant) & 1.070 & .162 & & 6.597 & .000 & & \\
\hline \multicolumn{7}{|l|}{ Practices } & 1.347 \\
\hline Loan Repayment & .446 & .045 & .474 & 10.010 & .000 & .742 & 1.347 \\
\hline Management & $\mathbf{R}$ & R2 & Adj. $R^{2}$ & $\mathbf{F}$ & Sig. & & \\
\hline & $.672^{a}$ & .452 & .449 & 135.782 & $.000^{b}$ & & \\
\hline \multicolumn{8}{|c|}{ Note: $n=166$ branches, a. Dependent Variable: Profitability, Durbin-Watson=1.682 } \\
\hline
\end{tabular}

tation, appraisal, and approval before actual disbursement would minimize bad loans and arrears which would subsequently enhance profitability. Based on these observations, it is emphasized that lending institutions should ensure effective credit risk

Management practices enhancing return on equity and operating income. This is in line with Fredrick (2012) who highlighted that credit management practices determine profitability since it focuses on minimizing the risk of default associated with loans which is the core source of revenue for lending institutions.

Recall that credit management practices are explained by a trilogy of documentation, appraisal, and approval. The findings obtained that each of the constructs is positively associated with profitability. In other words, the study communicates that for credit management practices enhancing profitability, it is important for management to put in place effective policies and procedures which enhance loan documentation, appraisal, and approval process. Nevertheless, Ongore and Kusa (2013) established that credit management practices sometimes fail to achieve the profitability expectation of management. The contradiction in relation to the current and previous studies signifies the need for top management to ensure that the credit management practices in place are highly effective such that commercial banks branches can consistently improve profitability.

The findings propose that loan documentation should be hailed within branches such that loan files are made complete. By so doing, commercial banks branches would be able to improve loan interest subsequently contributing towards the ROA. 
These findings correspond with Mbroh and Assah (2015) who mentioned that documentation is an important component of credit management practices because it avails proper financial reports that can be genuinely based on in making effective profitable plans and decisions. Similarly, Mutua (2016) emphasized documentation as an important management practice in bolstering a firm's profitability levels. On the other hand, the findings reveal that conducting effective loan appraisal is necessary for

Enhancing the profitability of commercial banks' branches. This study stresses that branches should endeavor to identify genuine customers who are most likely to comply with terms and conditions and subsequently minimizes default risk. These findings are consistent with the earlier observation by Gatuhu (2013) who stressed that proper credit appraisal protects lending institutions from recording numerous nonperforming loans which affect profitability.

Similarly, the findings reveal that it is essential to carry out effective loan approval in order to create an avenue upon which the profitability of commercial banks branches can be enhanced. With loan approval, the credit committee expresses acceptance that the loan amount is worth to be risked with a specific client. Accordingly, the study emphasizes that before the credit committee fully accepts a loan to be disbursed, they should strongly believe that such amount will be recovered at the lowest possible costs in order not to encroach on the commercial bank's ability to become profitable. To achieve this, the study postulates that commercial banks branches should have independent loan approval committees, verify loans before fully approved, base decisions on client's history, and comply with the credit extension policy within the bank to enhance profitability. These findings contradict an earlier study by Kagoyire and Shukla (2016) which obtained no relationship between loan approvals and profitability. It was established that approval is subject to conflict of interest and undue influence. Perhaps, this study argues that the issues mentioned explain why the relationship was obtained, and further emphasizes that exercising professionalism and independence is indeed core in minimizing extending credit to clients who do not qualify to make recovery a costly activity.

Based on the aforementioned findings, the study emphasizes that credit management should not be directed towards a specific practice. Rather, commercial banks branches must ensure that

Right from when a client applies for a credit facility until when a decision to extend or not to extend credit is determined, proper systems are in place. These are expressed in terms of documentation, appraisal, and approval processes.

\section{Loan Repayment Management and Prof- itability}

The findings of the study obtained a positive relationship between loan repayment management and profitability among commercial banks branches. It is confirmed that with loan repayment management in place, tendencies of nonperforming loans are bound to decline within commercial banks branches while operating income is bound to increase which would have a direct effect on the ROA, operating income, and minimize operating expenses. This study further points out the need for commercial banks branches to ensure that customers' adherence to terms and conditions which is a precondition for determining default rate, arrears, accrued loan interest which have a direct bearing on profitability. Worth noting, loan repayment management is mainly focused on ensuring that commercial banks branches minimize non-performing loans and improve credit administration.

The findings are consistent with earlier studies such as Asantey and Tengey (2014) who emphasized that loan repayment management enables financial institutions to minimize nonperforming loan portfolios which subsequently improve profitability. The findings were also found to concur with Amoako (2016) who emphasized that loan repayment management promotes external investment because they are sure that by investing, they would be able to generate a return. Therefore, the study communicates that loan repayment management has a direct inclination on the rate of non-performing loans and the credit administration within commercial banks branches and subsequently determines the profitability levels. Therefore, the

The current study sends a signal to the credit team that if banks are to become profitable, then they must ensure that they not only extend loans through disbursement but further closely monitor the way clients fulfill their obligations.

Importantly, the findings emphasize that where commercial banks' branches appropriately man- 
age credit limits, update lending policies and procedures regularly and effectively implement the policies and guidelines, they would be able to minimize errors within the lending process. As a consequence, commercial banks branches would be able to enhance return on assets exhibited in increased gross profit, net sales, and interest income. Moreover, the findings also suggest that when the credit policy is accessible by everyone, it would guide the work of all officers which would improve compliance and aggressiveness to contribute towards loan recovery. This is in line with earlier findings by Ebba (2016) who reported that financial institutions must deal properly with the increasing non-performing loans through an effective credit administration plan in order to increase cost efficiency and returns on assets and operating income.

Mediation effect of loan repayment management in the relationship between credit management practice and profitability

It was established that loan repayment management is a significant mediator in the relationship between credit management practices and profitability. The current study points out that much as effectively carrying out loan documentation, appraisal and approval are important in enhancing profitability, more improvement would be exhibited if commercial banks branches put mechanisms in place which boost performing loans. This is so because such institutions would be able to minimize arrears rates, bad debts, and portfolios at risk which have a direct bearing on the amount of revenue generated from loans. These findings are in complement some of the

Available literature. For instance, an earlier study by Wanjira (2010) established that through credit management practices, financial institutions are able to enhance loan repayment management and which subsequently determines the profitability in the long run. With the same view, Nyasaka (2017) revealed that financial institutions should mind of loan repayment management since it determines what credit management practices must be adopted in order to reinstate a profitable business.

It is widely accepted that empirical evidence to explain the mediation of loan repayment management in the relationship between credit management practices and profitability is still existent in their abstract (Kagoyire \& Shukla, 2016; Mwinlaaru et al., 2016; Vinh, 2017). The findings of this study, therefore, add value by adding to what is literally less known. In essence, the study points out that when commercial banks branches follow a specific document checklist for every loan that is prepared, ensure that details of collateral, credit history, and specific personal information are on file, they would be able to minimize default risk. However, the study affirms that with the intensity of loan repayment management, commercial banks branches effectively monitor such loans to ensure that they do not become aged, ensure that repayments are timely and in full installment to minimize accrued loan interest to subsequently reveal better profitability. The findings also put into consideration that much as financial analysis can be presented and a decision made upon approval, it is likely that the client may encounter challenges paying back as economic times change. But effective loan repayment management would ensure that the client is effectively monitored and where necessary, a suggestion to reschedule the loan such that it does not go in arrears. This would have a direct effect on the interest income that the bank would be able to generate within a specific period. In the same context, Mbucho (2015) elaborated that credit management policies target improving loan

Repayment management since it barely determines whether lending institutions can be profitable or not.

In addition, the findings suggest that loan appraisals are necessary, although effective loan repayment management is more likely to supplement its relevance. Elaborately, this study indicates that when commercial banks branches set up an independent credit team responsible for appraising loans, carries out know your customer (KYC), and endeavor to extend credit to clients upon ascertaining the primary loan purpose, it would enable institutions to make informed decisions. Coupled with loan repayment management, commercial banks branches would be able to minimize write-offs and enhance profitability. The findings concur with earlier findings by ChidoMakomeke et al., (2016) who revealed that the purpose of credit appraisal is to ensure that the right decision whether or not to extend credit is made. In this essence, it can be concluded that loan appraisal has the potential to influence loan repayment and subsequently profitability. 
In addition, the findings emphasize the need to effectively approve and monitor loans to guarantee profitability. The study suggests that for effective loan approval, it is necessary to have an independent loan approval committee, verification prior to actual approval, consider client's history and adopt flexible policies because these practices are bound to affect non-performing loans and subsequently profitability. This study established that when the right amount of loan is extended to a client, it becomes easy for them to fulfill their obligations which enables banks to register more performing loans which would exhibit in the timely installment and payment within the specified loan period to allow institutions generate income timely. The findings are consistent with earlier findings earlier empirical studies such as Wachira (2017) who conclusively stated that credit management is more of an input concept which for both

Profitability and loan repayment management. Credit management practices can effectively influence profitability, although the impact is more intense if commercial banks branches improve loan repayment management.

Based on the aforementioned, it is clear that the loan process must be managed in its completeness if commercial banks' branches are to generate profit. By conducting credit management practices, commercial banks' branches would be able to extend credit to the right clients. On the other hand, loan repayment management would enable commercial banks' branches to closely monitor clients such that they comply with the terms and conditions upon which credit is extended. It is no doubt that when clients comply with terms and conditions, commercial banks' branches would be able to become profitable.

Credit Management Practices, Loan Repayment Management, and Profitability

The findings obtained that credit management practices and loan repayment management are significant predictors of profitability. The findings affirm that if commercial banks' branches are to change the current position of profitability, they must do so through effective documentation, appraisal, and approval. The current study confirms that carrying out effective credit management practices enables commercial banks' branches to identify less risky clients who would easily comply with terms and conditions to minimize the cost of recovering such funds. In addition, the findings em- phasize the need to put in place effective loan repayment management if such institutions are to stimulate ROE, operating income and subsequently minimize operating expenses. The findings are consistent with Escalante et al., (2016) who indicated that credit management practices are important in ensuring that credit extended to clients is paid on time which affects profitability. The findings are also consistent with Nkundabanyanga et al., (2017)

who highlighted that effective credit management is linked to profitability since it manages customer credit lines and minimizes exposure to bad debt.

In the same vein, this study indicates that when loan repayment management is intensified, so would the profitability level. This is because the profitability of commercial banks' branches along with other lending institutions is largely vested in regards to the loan installment, timeliness of the installment, and the ability of clients to pay within the agreed loan duration. This study puts it clearly that it is necessary to put in place pre and postdisbursement if commercial banks' branches are to stimulate profitability. This also further affirms that the loan cycle is a continuous process that starts from the time a client expresses interest in a loan facility, through to approval or rejection of a loan amount until such a client pays off. The findings are in line with an earlier study by Njenga (2014) who emphasized that loan repayment management intensifies policies and procedures necessary for minimizing non-performing loans and operating expenses which boost profitability in the long run.

The findings also revealed that much as both credit management practices and loan repayment management are significant in predicting profitability among commercial banks' branches, better predictability of profitability is explained by loan repayment management. This study suggests that much as credit management practices enable commercial banks' branches to selectively allocate credit, the ability to recover the disbursed amount would matter significantly in explaining the level of profitability. Indeed, the study reveals that income inclined to credit is only attainable when such loans are paid. On the other hand, the study postulate that credit management practices only enable companies to minimize risk exposure as a result of rendering credit, but do not guarantee such loans will be paid accordingly. In this essence, it is conclusive 
That credit management practices serve as facilitators of loan repayment management. However, the findings contradict Abiola and Olausi (2014) who earlier stressed that loan repayment management is unlikely where credit management practices are less applied. With the same view, Waweru and Spraakman (2012) obtained that credit management is the driving force determining loan portfolio quality portfolio, which is the primary resource for profitability among lending institutions.

\section{Conclusion}

It has been revealed that effective credit management practice is necessary for commercial banks' branches to generate profits. In this regard, this study informs that when proper documentation, loan appraisal, and approval practices are enhanced, branches will become profitable.

The study proves that when branches for commercial banks' branches intensify loan repayment management in such a way that they minimize nonperforming loans and strengthen credit policies, they will stand a chance of improving ROA, operating income and reduce operating expenses substantially.

Further, it has been established that credit management practices partially require effective loan repayment management to fully determine the profitability of branches. Hence, it is important for commercial banks' branches to continually put clear mechanisms which are able to minimize nonperforming loans and stimulate credit policies.

It has been proved that credit management practices and loan repayment management are predictors of profitability. More so, the study confirms that when branches put more emphasis on loan repayment management, then they will become more profitable.

\section{Recommandations}

Based on the findings of the study, the following recommendations are put forward;

Commercial banks through branches should carry out continuous loan monitoring and control to ensure that customers promptly fulfill their payments on time. They should serve reminders and carrying out surprise client audits to ensure they meet their obligations as expected.

Commercial banks should be in constant contact with all loan customers to understand them better. This will enable the banks to offer workable solutions in case of indications of default/loan becoming nonperforming. Applicable strategies could be; rescheduling the loan, amalgamation of different loans, waiver of interest, and extension of loan period among others.

Commercial banks through branches should ensure that all loan files are complete in a documentation context. The credit committee should ensure that the documentation checklist is complied with through a physical correspondence exercise.

Commercial banks through branches should improve the way they appraise clients before extending credit to them. They should ensure that the pledged securities are fully verified, ascertain the main purpose of the loan, appropriate loan amount, and period to minimize over or under funding clients as both extremes affect the client's ability to pay.

\section{Limitations of the Study}

There is no research without limitations. The main concern is that the study on only commercial banks' branches in a locus of the different financial institutions that comprise the financial sector. The study was a cross-sectional design. In this regard, the study was unable to capture the changes that occurred to the studied variables over a period of time as the study was being conducted. Last but not least, by adopting a closed-ended questionnaire, it was practically unlikely that the study would be able to understand the "why?" respondents answered the way they did.

\section{Areas for Further Study}

i.) Longitudinal study on the relationship between credit management practices, loan repayment management, and profitability among financial institutions in Uganda.

ii.) Conduct mixed research on the relationship between credit management practices, loan repayment management, and profitability among financial institutions in Uganda.

\section{Examine the factors influencing loan repayment}

Management among financial institutions in Uganda.

\section{ACKNOWLEDGMENT}

To have this research work completed was not a simple task. It was not only my own effort but a 
result of support from many people whom all I can not mention. To begin with, I thank the Almighty God for enabling me to put together this piece of work. Secondly, my sincere appreciation goes to my research supervisors; Dr. Nkote Isaac Nabeta and Mr. Okumu Moses who were directly involved. I thank them for their tireless reviews; guidance and patience that enabled me to complete this research.

With heartfelt gratitude, I do acknowledge my wife Helen Peace Fuambe Elemu for the inspiration, encouragement, and social support. I would also like to acknowledge my parents, colleagues, MBA classmates, friends, and relatives who encouraged and prayed for me during my MBA journey and this project. May God bless you!

\section{A References:}

1. (Master's Thesis, University of Essex).

2) Abbasi, T., \& Weigand, H. (2017). The Impact of Digital Financial Services on Firm's Performance in Netherlands: International journal of economics and management, 5(3), 1-15.

3) Abiola, I., \& Olausi, A. S. (2014). The impact of credit risk management on the commercial banks performance in Nigeria. International Journal of Management and Sustainability, 3(5), 295-306.

4) Adekunle, O., Alalade, S. Y., Agbatogun, T., \& Abimbola, C. (2015). Credit Risk Management and Financial Performance of Selected Commercial Banks in Nigeria. Journal of Economic \& Financial Studies, 3(01), 01-09. https://doi.org/10.18533/jefs. v3i01.73

5) Amin, M.E. (2005). Social Science Research: Conception, Methodology and Analysis. Makerere University Press, Kampala

6) Amoako, K. A. (2016). The effect of bad loans on the profitability and lending potential of rural banks. A case study of some selected rural banks in the Ashanti Region (Doctoral dissertation, University of Ghana).

7) Asante, Y. A. (2016). Assessing Credit Credit Management Practices in Savings \& Loans Companies: A Case Study of First Allied Savings \& Loans Ltd, Ksi (Doctoral dissertation).

8) Asantey, J. O., \& Tengey, S. (2014). An Empirical Study on the Effect of Bad Loans on Banks 'Lending Potential and Financial Performance: The Case of SMEs-Lending in Ghana. Impact: International Jour- nal of Research in Business Management (IMPACT: IJRBM), 2 (11), 1-12.

9) Balango, T.K., \& Rao, M.K. (2017). The effect of NPL on profitability of banks with reference to commercial bank of Ethiopia. Business and Management Research Journal, 7(5): 45- 50.

10) Bank of Uganda (2016b). Financial Stability Report. June 2016, Issue No. 8. Retrieved from https://www.bou.or.ug/bou/bou-downloads /financial_stability/Rpts/All/Financial-Stability-Repo rt--June-2016.pdf.

11) Bank of Uganda (2015). Annual Supervision Report, 6. Retrieved from https://www.bou.or.ug/b ou/download_archive.html?path=/bou/bou- downloads/asr/\&title=Supervision\&subtitle=Annual\%20Supervision\% e=binary\&secname=\&year $=2015 \&$ month $=$ Dec (Accessed on 26th April 2018).

12) Bank of Uganda (2016a). Annual Supervision Report, 7. Retrieved from https://www.bou.or.ug/b ou/download_archive.html?path=/bou/bou- downloads/asr/\&title=Supervision\&subtitle=Annual\%20Supervision\% e=binary \&secname $=\& y e a r=2016 \&$ month $=D e c$ (Accessed on 26th April 2018).

13) Cronbach, L. J. (1951). Coefficient alpha and the internal structure of tests. psychometrika, 16(3), 297-334. https://doi.org/10.1007/BF02310 555

14) Cucinelli, D. (2015). The impact of nonperforming loans on bank lending behavior: evidence from the italian banking sector. Eurasian Journal of Business and Economics, 8(16), 59- 71. h ttps://doi.org/10.17015/ejbe.2015.016.04

15) Delen, D., Kuzey, C., \& Uyar, A. (2013). Measuring firm performance using financial ratios: $A$ decision tree approach. Expert Systems with Applications, 40(10), 3970-3983. https://doi.org/10.1016 /j.eswa.2013.01.012

16) Ebba, M.K. (2016). The relationship between loan repayment management and financial performance of commercial banks in Ethiopia (Master's Thesis, University of Nairobi).

i. Educational and psychological measurement, 30(3), 607-610.

17) Escalante, C., Song, M., \& Dodson, C. (2016). FSA farm loan repayment under economic recession and drought conditions: evidence from US southeastern and Midwestern farms. Agricultural Finance Review, 76(4), 445-461. https://doi.org/10. 1108/AFR-07-2016-0063

18) Fendi, U. A., Sawalha, I. H. S., Shamieh, J., \& Jaara, O. O. (2017) Early Warning Indicators for Mon- 
itoring Non-Performing Loans in Jordanian Banking System, International Journal of Business and Social Science, 8(6), 105-115.

19) Field, A. P. (2009). Discovering statistics using SPSS: (and sex and drugs and rock ' $n$ ' roll). Los Angeles [i.e. Thousand Oaks, Calif.: SAGE Publications

20) Glover, J. \& Levine, C. (2016). Information Asymmetries about Measurement Quality. doi: 10.1111/1911-3846.12434 https://doi.org/10.1111 /1911-3846.12434

21) Gul, S., Irshad, F. \& Zaman, K. (2011). Factors affecting bank profitability in Pakistan. The Romanian Economic Journal, 15(39), 61-87.

22) Hassanpoor, D. \& Pourali, M.R. (2013). The Relationship between Return on Equity and Investment Opportunities of the Firms Listed in Tehran Stock Exchange, Research Journal of Recent Sciences, 3(9), 10-14.

23) Heikal, M., Khaddafi, M., \& Ummah, A. (2014). Influence analysis of return on assets (ROA), return on equity (ROE), net profit margin (NPM), debt to equity ratio (DER), and current ratio (CR), against corporate profit growth in automotive in Indonesia Stock Exchange. International Journal of Academic Research in Business and Social Sciences, 4(12), 101 - 114. https://doi.org/10.6007/IJARBSS/v4-i12/1 331

24) Hernaus, T., Bach, M.P. \& Vukšić, V.B (2012). Influence of strategic approach to BPM on financial and non-financial performance, Baltic Journal of Management, 7(4), 376-396, https://doi.org/10.110 8/17465261211272148

25) Kagoyire, A., \& Shukla, J. (2016). Effect of Credit Management on Performance of Commercial Banks in Rwanda (A Case Study of Equity Bank Rwanda Ltd). International Journal of Business and Management Review, 4(4), 1-12.

26) Kazan, H. Özer, G. \& Çetin, A.T. (2006). The effect of manufacturing strategies on financial performance", Measuring Business Excellence, 10(1),1426. https://doi.org/10.1108/13683040610652186

27) Kessey, K. D. (2015). Assessing Credit Risk Credit Management Practices in the Banking Industry of Ghana: Processes and Challenges. Global Journal of Management and Business Research, 15(6), 1-10.

28) Kharatyan, D., Lopes, J., \& Nunes, A. (2017). Determinants of return on equity: evidence from NASDAQ 100. XXVII Jornadas Hispano-Lusas Gestión Científica.
29) Klotz, S. \& Lindermeir, A. (2015). Multivariate credit portfolio management using cluster analysis, The Journal of Risk Finance, 16(2), 145-163 https:// doi.org/10.1108/JRF-09-2014-0131

30) Krejcie, R. V., \& Morgan, D. W. (1970). Determining sample size for research activities. https://d oi.org/10.1177/001316447003000308

31) Lagat, F., Mugo, R., \& Otuya, R. (2013). Effect of Credit Risk Credit Management Practices on Lending Portfolio Among Savings and Credit Cooperatives in Kenya. European Journal of Business and Management, 5(19), 3-19.

32) Mbroh, J. K., \& Assah, B. (2015). Financial Records Keeping and Business Decision Making Practices by Small and Micro Enterprise Owners in Ghana-Evidence from The Central Region. International Journal of Economics, Commerce and Management, 3(8), 23-29. https://doi.org/10.11648 /j.ijefm.20150305.21

33) Mbucho, C. W. (2015). Influence of credit management on the loan performance among microfinance institutions in Kenya. Strategic Journal of Business \& Change Management, 2(2), 35-56.

34) Menicucci, E. \& Paolucci, G. (2016). The determinants of bank profitability: empirical evidence from European banking sector", Journal of Financial Reporting and Accounting, 14 (1), 86-115. https ://doi.org/10.1108/JFRA-05-2015-0060

35) Muritala, T.A., \& Taiwo, A.S. (2013). Credit Management Spur Higher Profitability? Evidence from Nigerian Banking Sector. Journal of Applied Economics and Business, 1(2), 46-53.

36) Mwinlaaru, P. Y., Ofori, I. K., Adiyiah, K. A., \& Idun, A. A. A. (2016). Loan repayment management and Universal Bank's Profitability, Journal of Productivity Analysis, 44(3), 265-281.

37) Njenga, B. (2014). The effects of credit credit Management Practices on loan performance in deposit taking microfinance institutions in Kenya (Master's Thesis, University of Nairobi).

38) Nkundabanyanga, S. K., Akankunda, B., Nalukenge, I., \& Tusiime, I. (2017). The impact of financial management practices and competitive advantage on the loan performance of MFIs. International Journal of Social Economics, 44(1), 114-131. https://doi.org/10.1108/IJSE-05-2014-0104

39) Nunnally, J. C. (1978). Psychometric theory (2nd ed.). New York: McGraw-Hill.

40) Nyasaka, F. O. (2017). The Relationship between Credit Risk Credit Management Practices and Loan repayment management in Kenyan Commer- 
cial Banks: A Case Study of KCB Group Limited (Doctoral dissertation, United States International University-Africa).

41) Ongore, V. O., \& Kusa, G. B. (2013). Determinants of financial performance of commercial banks in Kenya. International Journal of Economics and Financial Issues, 3(1), 237-252.

42) Ozili, P. K. (2017). Loan repayment management and Financial Development: New Evidence ht tps://doi.org/10.2139/ssrn.2892911

43) Raghunandan, M., Ramgulam, N., Raghunandan-Mohammed, K., \& Allaham, I. (2012). Emerging issues on the horizon: Financial services industry in Trinidad and Tobago. International Journal of Humanities and Social Science, 2(17), 55-69.

44) Sobel, M. E. (1982). Asymptotic confidence intervals for indirect effects in structural equation models. Sociological methodology, 13, 290-312. htt ps://doi.org/10.2307/270723

45) Tebajjukira, A., \& Joji, C. (2015). Ranking of Commercial Banks in Uganda: A Comparative Analysis. International Journal of Multidisciplinary and Current Research, 3, 1219-1222

46) Uwuigbe, U., Uwuigbe, O. R., \& Oyewo, B. (2015). Credit Management and Bank Performance of Listed Banks in Nigeria, Journal of Economics and Sustainable Development, 6(2), 27-32.

47) Vinh, N. T. H. (2017). The impact of loan repayment management on bank profitability and lending behavior: Evidence from Vietnam. Journal of Economic Development, 24 (3), 27-44. https://do i.org/10.24311/jed/2017.24.3.06

48) Wachira, A. K. (2017). Effects of credit risk credit Management Practices on loan performance of commercial banks in Nyeri County, Kenya. International Journal of banking and finance Economic and Financial Research, 5(1), 135-152.

49) Wanjira, T. L. (2010). The relationship between loan repayment management credit Management Practices and financial performance of commercial banks in Kenya, (Masters Thesis, University of Nairobi).

50) Waweru, N., \& Spraakman, G. (2012). The use of performance measures: case studies from the microfinance sector in Kenya. Qualitative Research in Accounting \& Management, 9(1), 44-65. https:// doi.org/10.1108/11766091211216105

51) Winterboer (2016). Financial institutions progress in Africa: How banks are dealing with loan repayment to become profitable. Retrieved from: https://en.wikipedia.org/wiki/African_Bank_ Limited. (Accessed on: October 4, 2019).

52) Zu, X., \& Kaynak, H. (2012). An agency theory perspective on supply chain quality management. International Journal of Operations \& Production Management, 32(4), 423-446. https://doi.org/10.11 08/01443571211223086 